\title{
HUBUNGAN KADAR LEMAK DALAM ASI MATUR DENGAN PENAMBAHAN BERAT BADAN BAYI UMUR 1-2 BULAN DI PUSKESMAS JABUNG
}

\author{
Yunita Afrilia, Afnani Toyibah, Ita Yuliani \\ Poltekkes Kemenkes Malang, Jl. Besar Ijen No 77 C Malang \\ yurito04@gmail.com
}

(Relationship Of Fat Levels In Matile Assembly With Addition To Age Of Baby Agency 1-2 Months In Jabung Health Center)

Abstract: Malnutrition in infants can be measured using the body weight index by age (BB / $U$ ) Baby's weight can be given by several factors one of which is breast milk intake. A preliminary study shows that mothers who exclusively breastfeed with the frequency and duration of breastfeeding are both old-fashioned babies in weight gain in infants. This can be caused by one of the factors that fat content in breast milk, because the fat content in breast milk is needed for the baby's weight gain. The purpose of this study was to determine the relationship of fat content in breast milk with the addition of infant weight. The design of associative research with cross sectional approach, the population of 41 breastfeeding mothers, sampling using quota sampling technique with the number of samples of 37 respondents breastfeeding mothers who meet the inclusion criteria. The research instrument using scales, microtoice and extracted soxhlet, then analyzed with the words Product moment that shows the value of rhitung $=0.706>r$ tabel $=0.325$ so it shows the relationship between fat content in breast milk with baby weight gain.

Keys Word : Fats Content in Breast Milk, Adding Baby Weight

\begin{abstract}
Abstrak: Kekurangan gizi pada bayi dapat diukur menggunakan indek berat badan menurut umur $(\mathrm{BB} / \mathrm{U})$. Berat badan bayi dapat dipengaruhi oleh beberapa faktor salah satunya ada asupan ASI. Studi pendahuluan menunjukkan bahwa, ibu yang memberikan ASI secara ekslusif dengan frekuensi dan durasi menyusui baik namun terjadi permasalan pada penambahan berat badan pada bayi. Hal tersebut bisa diakibatkan oleh salah satu faktor yaitu kandungan lemak dalam ASI, karena kandungan lemak dalam ASI sangat diperlukan untuk penambahan berat badan bayi. Tujuan dari penelitian ini adalah untuk mengetahui hubungan kadar lemak dalam ASI Matur dengan penambahan berat badan bayi. Desain penelitian asosiatif dengan pendekatan cross sectional, populasinya sebanyak 41 orang ibu menyusui, sampling menggunakan teknik quota sampling dengan jumlah sampel sebanyak 37 responden ibu menyusui yang memenuhi kriteria inklusi. Instrumen penelitian mengunakan timbangan, microtoice dan di ekstrasi soxhlet, kemudian di analisa dengan korelasi Product moment yang menunjukkan nilai $r_{\text {hitung }}=0,706>r_{\text {tabel }}=0,325$ sehingga menunjukkan adanya hubungan antara kadar lemak dalam ASI Matur dengan penambahan berat badan bayi.
\end{abstract}

Kata Kunci : Kadar Lemak dalam ASI, Penambahan Berat Badan Bayi 


\section{PENDAHULUAN}

Air Susu Ibu (ASI) adalah makanan pertama, utama dan terbaik bagi bayi yang bersifat alamiah, dan mengandung berbagai zat gizi yang dibutuhkan dalam proses pertumbuhan dan perkembangan bayi (Prasetyo, 2008). Air Susu Ibu (ASI) merupakan makanan yang mudah didapat, selalu tersedia, siap diminum tanpa adanya persiapan yang khusus dengan temperatur yang sesuai dengan bayi. Air Susu Ibu (ASI) memiliki kandungan zat gizi yang lengkap dan sempurna untuk keperluan bayi serta mengandungi zat anti infeksi. Oleh karena itu, Air Susu Ibu (ASI) merupakan satusatunya makanan yang terbaik untuk bayi umur 0-6 bulan (Ruliana, 2004).

ASI dibagi menjadi 3 jenis berdasarkan waktu diproduksi atau stadium laktasi yaitu kolostrum, air susu masa peralihan (masa transisi), dan air susu mature. Kolostrum merupakan ASI yang dikeluarkan hari-hari pertama setelah melahirkan, sangat kental dan berwarna kekuning-kuningan yang memberikan perlindungan terhadap infeksi pada bayi serta memiliki efek laktasif (pencahar) yang dapat membantu bayi mengeluarkan feses/tinja pertama (Monika, 2015). ASI transisi atau ASI peralihan adalah ASI yang dihasilkan setelah kolostrum, yang biasanya keluar selama 2 minggu. ASI peralihan mengandung lebih banyak kalori dibandingkan dengan kolostrum (Lesmana dkk, 2011). ASI matur merupakan ASI yang disekresi pada hari ke 10 dan seterusnya dan dikatakan komposisinya relatif konstan yaitu pada minggu ke 3 sampai ke 5 (Marmi, 2012). ASI matur terbagi dalam 2 jenis yaitu foremilk dan hindmilk. Foremilk adalah ASI yang dihasilkan selama awal menyusui, foremilk banyak mengandung air, vitamin, dan protein. Warnanya cenderung lebih jernih dan encer dibandingkan dengan hindmilk. Hindmilk adalah ASI yang keluar setelah foremilk habis, warnanya cenderung lebih putih dan lebih kental mengandung lemak yang sangat diperlukan untuk penambahan berat badan bayi (Monica, 2015). Komposisi nutrisi ASI pada semua ibu menyusui sama, namun yang membedakan adalah kualitas atau kadarnya. Menurut Lawrance (2011) dalam Monika (2015) presentase setiap komposisi dalam ASI normalnya yaitu $88,1 \%$ air, $3,8 \%$ lemak, $0,9 \%$ protein, $7 \%$ laktosa dan $0,2 \%$ bahan-bahan lain.

Bayi umur 0-5 bulan membutuhkan energi sebesar 550 kkal untuk memenuhi kebutuhan pertumbuhan dan perkembangannya. Kebutuhan energi tersebut dapat dipenuhi dengan memberikan ASI secara Eksklusif sampai umur 6 bulan. Komposisi ASI yang paling banyak memenuhi kebutuhan energi adalah lemak, lemak pada ASI memenuhi $50 \%$ kebutuhan energi untuk pertumbuhan berat badan dan perkembangan saraf bayi. Lemak paling banyak di produksi pada tahapan ASI matur di akhir proses penyusuan (hindmilk) yang sangat berperan dalam pertambahan berat badan bayi (Andriani, 2012).

Pemantauan Status Gizi (PSG) tahun 2015 yang dilakukan diseluruh kabupaten dan kota diseluruh Indonesia yang dilakukan pada \pm 165.000 balita sebagai sampel. Status Gizi Balita menurut Indeks BB/U didapatkan hasil 79,7\% gizi baik, $14,9 \%$ gizi kurang, 3,8\% gizi buruk dan $1,5 \%$ gizi lebih. Hasil Studi pendahuluan di wilayah kerja Puskesmas Jabung Kabupaten Malang pada tahun 2016 didapatkan cakupan ibu menyusui sebesar 213 orang, $97 \quad(45,5 \%)$ ibu menyusui dengan ASI Eksklusif dan 116 $(54,5 \%)$ ibu menyusui tidak ASI Eksklusif. Pada bulan Januari didapatkan 15 ibu menyusui yang memiliki bayi umur 1-2 bulan dengan ASI ekslusif, frekuensi menyusui rata-rata 8-10 kali dengan lama menyusui 15-30 menit. Bayi dilakukan penimbangan berat badan dan di klasifikasikan menggunakan KMS untuk kenaikan berat badan bayi, 7 dari 15 $(46,67 \%)$ bayi tidak mengalami kenaikan berat badan sedangkan 8 dari $15(53,33 \%)$ bayi mengalami kenaikan berat badan . 
Dari data tersebut, peneliti menemukan ibu yang menyusui secara eksklusif dengan frekuensi 8-10 kali dan lama menyusui 15-30 menit namun bayi tidak mengalami kenaikan berat badan. Penelitian sebelumnya yang dilakukan oleh Rogawski (2005) yang meneliti tentang pemberian lemak pada bayi yang lahir premature melalui pemberian asupan lemak parenteral melalui infis menunjukkan hasil bahwa dapat mengurangi resiko terjadinya kekurangan asam lemak bebas (Free Fat Acids/FFA) dan mencegah kekukrangan (Essential Fatty Acids/EFA). Lemak yang terdapat dalam ASI adalah lemak raantai panjang yang mudah dicerna oleh tubuh bayi sehingga mampu membantu pertumbuhan berat badan bayi.

Tujuan umum penelitian ini adalah untuk mengetahui hubungan antara kadar lemak dalam asi matur dengan penambahan berat badan bayi umur 1-2 bulan. Tujuan khusus penelitian ini antara lain: mengidentifikasi kadar lemak dalam ASI Matur, mengidentifikasi penambahan berat badan bayi umur 1-2 bulan, dan Menganalisa hubungan kadar lemak dalam ASI matur dengan penambahan berat badan bayi umur 1-2 bulan.

Hasil penelitian ini diharapkan dapat digunakan sebagai asuhan kebidanan tambahan pada ibu menyusui dalam produksi ASI.

\section{METODE PENELITIAN Disain Penelitian}

Desain penelitian ini adalah asosiatif yaitu akan dicari hubungan antara kadar lemak dalam ASI matur dengan penambahan berat badan bayi umur 1-2 bulan yang menggunakan pendekatan Cross Sectional yaitu penambahan berat badan bayi dan kadar lemak dalam ASI matur diukur hanya satu kali pada suatu saat yang bersamaan.

\section{Populasi}

Populasi dalam penelitian ini adalah seluruh ibu menyusui dengan ASI
Ekslusif yang memiliki bayi umur 1-2 bulan di Puskesmas Jabung -Malang pada bulan Juni 2017 dengan jumlah populasi \pm 41 ibu menyusui.

\section{Sampel}

Besar sampel dalam penelitian ini dihitung dengan menggunakan rumus Isaac dan Michael dikarenakan populasinya telah diketahui dengan tingkat kesalahan 5\%, maka jumlah anggota sampel sebesar 37 ibu menyusui dengan ASI Ekslusif yang memiliki bayi umur 1-2 bulan.

\section{Teknik Sampling}

Penelitian ini menggunakan teknik Quota Sampling

\section{Variabel Penelitian}

Penelitian ini menggunakan dua variabel, yaitu :

a. Variabel bebas (independen)

Variabel independen dalam penelitian ini adalah kadar lemak dalam ASI matur.

b. Variabel terikat (dependen)

Variabel dependen dalam penelitian ini adalah penambahan berat badan bayi umur $1-2$ bulan

\section{Kriteria Inklusi}

Kriteria inklusi pada penelitian ini adalah ibu menyusui secara Eksklusif yang:

a. Ibu yang telah melahirkan bayi dengan usia kehamilan aterm

b. Berat badan bayi lahir normal

c. Ibu yang hanya memberikan ASI pada bayinya

d. Bayi yang tidak memiliki cacat bawaan

e. Jenis persalian normal

f. Ibu yang tidak berpantang makanan

g. Frekuensi menyusui 8-12 kali sehari

h. Ibu yang tidak menggunakan alat kontrasepsi hormonal kombinasi

\section{Kriteria Eksklusi}


Kriteria eksklusi pada penelitian ini adalah Ibu yang memiliki kelainan pada payudara.

\section{Tempat dan Waktu Penelitian}

Pengambilan data dilaksanakan di Puskesmas Jabung Kabupaten Malang, dan pemeriksaan kadar lemak dalam ASI dilakukan di Laboratorium Sentral Ilmu Hayati (LSIH) Fakultas Pertanian Universitas Brawijaya selama bulan Juni 2017

\section{Definisi Operasional}

\begin{tabular}{|c|c|c|c|c|}
\hline $\begin{array}{l}\text { Vari } \\
\text { abel }\end{array}$ & $\begin{array}{c}\text { Definisi } \\
\text { Operasio } \\
\text { nal }\end{array}$ & $\begin{array}{l}\text { Alat } \\
\text { Ukur }\end{array}$ & $\begin{array}{l}\text { Skala } \\
\text { Ukur }\end{array}$ & Kategori \\
\hline $\begin{array}{l}\text { Kadar } \\
\text { lemak } \\
\text { dalam } \\
\text { ASI } \\
\text { matur }\end{array}$ & $\begin{array}{l}\text { Jumlah } \\
\text { kuantitas } \\
\text { lemak } \\
\text { dalam } \\
\text { ASI } \\
\text { Matur } \\
\text { yang } \\
\text { tentukan } \\
\text { secara } \\
\text { laboratori } \\
\text { um } \\
\text { melalui } \\
\text { teknik } \\
\text { analisa } \\
\text { sokhlet }\end{array}$ & $\begin{array}{l}\text { Labo } \\
\text { ratori } \\
\text { um }\end{array}$ & Rasio & $\begin{array}{l}\text { Lemak: } \\
\text { a. Baik = } \\
\geq 3,8 \mathrm{~g} / \mathrm{dl} \\
\text { b. Tidak } \\
\text { Baik }=<3,8 \\
\mathrm{~g} / \mathrm{dl}\end{array}$ \\
\hline $\begin{array}{l}\text { Pena } \\
\text { mbah } \\
\text { an } \\
\text { Berat } \\
\text { bada } \\
\mathrm{n} \\
\text { bayi } \\
\text { usia } \\
1-2 \\
\text { bulan }\end{array}$ & $\begin{array}{l}\text { Jumlah } \\
\text { penamba } \\
\text { han berat } \\
\text { badan } \\
\text { bayi } \\
\text { sejak } \\
\text { lahir } \\
\text { hingga } \\
\text { penelitia } \\
\text { n } \\
\text { dilakuka } \\
\text { n yang } \\
\text { diukur } \\
\text { dengan } \\
\text { satuan } \\
\text { gram }\end{array}$ & $\begin{array}{c}\text { Timb } \\
\text { anga } \\
n \\
\text { berat } \\
\text { bada } \\
n \\
\text { bayi }\end{array}$ & Interval & $\begin{array}{l}\text { Umur 1 bln : } \\
\text { a. Kurang = } \\
<700 \\
\text { gr/bulan } \\
\text { b. Normal = } \\
700-1000 \\
\text { gr/bulan } \\
\text { c. Lebih = } \\
>1000 \\
\text { gr/bulan } \\
\text { Umur } 2 \text { bln : } \\
\text { a. Kurang = } \\
<1.400 \\
\text { gr/bulan } \\
\text { b. Normal = } \\
1.400-2.000 \\
\text { gr/bulan } \\
\text { c. Lebih = } \\
>2.000 \\
\text { gr/bulan }\end{array}$ \\
\hline
\end{tabular}

Teknik Pengumpulan Data
1) Melakukan kalibrasi pada timbangan berat badan di Dinas Perdagangan.

2) Menyaring calon responden berdasarkan kriteria inklusi

3) Menjelaskan kepada calon responden maksud dan tujuan penelitian

4) Memberikan surat pernyataan persetujuan menjadi responden

5) Bayi dilakukan penimbangan berat badan menggunakan timbangan berat badan bayi (SOP terlampir)

6) ASI ibu diperah sebanyak $50 \mathrm{~mL}$ menggunakan breast pump, di simpan di breastmilk bag yang telah diberikan label, dan diletakkan di dalam cool box (SOP terlampir)

7) ASI ibu yang sudah diperah dibawa ke laboratorium $\leq 2$ jam untuk diperiksa kadar lemak yang terkandung dalam ASI ibu. Pemeriksaan kadar lemak dilakukan oleh laboran di LSIH-UB (SOP terlampir)

8) Pengumpulan data yang telah selesai kemudian diolah untuk mengetahui hasil dari penelitian.

\section{Teknik Pengolahan Data}

Setelah data terkumpul selanjutnya diolah melalui tahap-tahap sebagai berikut:

1) Editing (memeriksa kembali)

Memeriksa kembali semua data yang telah dikumpulkan sehingga dapat digunakan sebagai responden dalam penelitian ini.

2) Coding (pemberian kode)

Memberikan kode pada responden bayi dan klasifikasi berat badan bayi serta kadar lemak ASI dengan angka untuk mempermudah dalam melakukan tabulasi dan analisa data

3) Entry data (memasukkan data)

Proses memasukkan data yang telah dikumpulkan ke dalam master tabel atau database komputer.

4) Tabulating

Data yang diperoleh atau dimasukkan dalam program SPSS, kemudian direkap dan disusun dalam bentuk tabel agar dapat dibaca dengan mudah. 
5) Uji statistic yang digunakan adalah Kolerasi Product Moment, dengan pertimbangan skala data yang dihasilkan adalah interval serta rasio. Uji statistik bertujuan untuk menguji hubungan Kadar lemak dalam ASI matur dengan penambahan berat badan bayi. Perhitungan uji statistik menggunakan fasilitas yang terdapat pada program SPSS.

\section{HASIL PENELITIAN}

Karakteristik responden berdasarkan umur bayi.

Di bawah ini disajikan hasil analisis distribusi frekuensi berdasarkan usia bayi yang dimiliki responden dalam penelitian.

\begin{tabular}{|c|c|c|}
\hline Tabel 1 & $\begin{array}{l}\text { : Distribusi } \\
\text { Karakteri } \\
\text { Berdasark } \\
\text { Puskesma } \\
\mathbf{2 0 1 7}\end{array}$ & \begin{tabular}{cr} 
Frekuensi \\
ik & Responden \\
in Usia Bayi di \\
\multicolumn{2}{c}{ Jabung, Tahun }
\end{tabular} \\
\hline Umur & Frekuensi & Persentase (\%) \\
\hline 1 Bulan & 23 & 62 \\
\hline 2 Bulan & 14 & 38 \\
\hline Total & 37 & 100 \\
\hline
\end{tabular}

Tabel 1 menunjukkan bahwa sebagian besar usia bayi yang dimiliki responden $(62 \%)$ adalah 1 bulan.

Karakteristik responden berdasarkan alat kontraseps yang digunakan.

Berikut ini disajikan hasil analisis distribusi frekuensi berdasarkan alat kontrasepsi yang digunakan responden dalam penelitian.

Tabel 2 : Distribusi

Frekuensi

Karakteristik Responden

Berdasarkan Alat Kontrasepsi yang Digunakan di Puskesmas Jabung, Tahun 2017

\begin{tabular}{|c|c|c|}
\hline $\begin{array}{c}\text { Alat } \\
\text { Kontrasespsi }\end{array}$ & Frekuensi & $\begin{array}{c}\text { Persentase } \\
(\mathbf{\%})\end{array}$ \\
\hline IUD & 2 & 5 \\
\hline Pil & 3 & 9 \\
\hline Suntik 3 Bulan & 12 & 32 \\
\hline MOW & 2 & 5 \\
\hline Tidak KB & 18 & 49 \\
\hline Total & $\mathbf{3 7}$ & $\mathbf{1 0 0}$ \\
\hline
\end{tabular}

Tabel 2 menunjukkan bahwa sebagian responden $(49 \%)$ tidak menggunakan alat kontrasepsi.

Hasil pengukuran kadar lemak dalam ASI.

Di bawah ini disajikan hasil analisis distribusi frekuensi berdasarkan hasil pengukuran kadar lemak dalam ASI dalam penelitian.

\begin{tabular}{|c|c|c|}
\hline Tabel 3 & $\begin{array}{l}\text { Distribusi } \\
\text { Karakteristik } \\
\text { Berdasarkan } \\
\text { Pengukuran } \\
\text { dalam ASI } \\
\text { Jabung, Tahı }\end{array}$ & $\begin{array}{l}\text { Frekuensi } \\
\text { Responden } \\
\text { Hasil } \\
\text { Kadar Lemak } \\
\text { li Puskesmas } \\
\text { n } 2017\end{array}$ \\
\hline $\begin{array}{l}\text { Kadar } \\
\text { Lemak }\end{array}$ & \begin{tabular}{l|l} 
& Frekuensi
\end{tabular} & $\begin{array}{c}\text { Persentase } \\
(\%)\end{array}$ \\
\hline Baik & 19 & 51 \\
\hline Tidak Baik & 18 & 49 \\
\hline Jumlah & 37 & 100 \\
\hline
\end{tabular}

Tabel 3 menunjukkan bahwa sebagian responden $(51 \%)$ memiliki kadar lemak baik.

Hasil pengukuran penambahan berat badan bayi

Di bawah ini disajikan hasil analisis distribusi frekuensi berdasarkan hasil pengukuran penambahan berat badan bayi dalam penelitian.

$\begin{array}{llr}\text { Tabel } 4 & \text { : Distribusi } & \text { Frekuensi } \\ & \text { Karakteristik } & \text { Responden } \\ \text { Berdasarkan } & \text { Hasil } \\ & \text { Pengukuran } & \text { Penambahan } \\ & \text { Berat Badan Bayi umur 1-2 } \\ & \text { bulan di } & \text { Puskesmas } \\ & \text { Jabung, Tahun 2017 }\end{array}$

\begin{tabular}{|c|c|c|}
\hline $\begin{array}{c}\text { Penambahan } \\
\text { BB Bayi }\end{array}$ & Frekuensi & Presentase \\
\hline Kurang & 10 & $19 \%$ \\
\hline Normal & 11 & $38 \%$ \\
\hline Lebih & 16 & $43 \%$ \\
\hline Jumlah & $\mathbf{3 7}$ & $\mathbf{1 0 0} \%$ \\
\hline
\end{tabular}

Tabel 4 menunjukkan bahwa hasil pengukuran penambahan berat badan bayi menunjukkan bahwa 16 responden (43\%) termasuk dalam kategori penambahan berat badan lebih. 
Tabulasi silang antara kadar lemak dalam ASI matur dengan penambahan berat badan bayi umur 1-2 bulan.

Di bawah ini disajikan hasil analisis tabulasi silang antara kadar lemak dalam ASI matur dengan penambahan berat badan bayi umur 1-2 bulan dalam penelitian.

\section{Tabel 5 : Tabulasi Silang Antara kadar lemak dalam ASI matur dengan penambahan berat badan bayi umur 1-2 bulan di Puskesmas Jabung, Tahun 2017}

\begin{tabular}{|l|c|c|c|c|}
\hline \multirow{2}{*}{$\begin{array}{c}\text { Kadar } \\
\text { Lemak }\end{array}$} & \multicolumn{2}{|c|}{ Penambahan BB Bayi } & \multirow{2}{*}{ Total } \\
\cline { 2 - 4 } & Kurang & Normal & Lebih & \\
\hline Tidak & 10 & 8 & 0 & 18 \\
Baik & $(56 \%)$ & $(44 \%)$ & $(0 \%)$ & $(\mathbf{1 0 0 \% )}$ \\
\hline Baik & 0 & 3 & 16 & 19 \\
& $(0 \%)$ & $(16 \%)$ & $(84 \%)$ & $(\mathbf{1 0 0 \% )}$ \\
\hline Total & $\mathbf{1 0}$ & $\mathbf{1 1}$ & $\mathbf{1 6}$ & $\mathbf{3 7}$ \\
& $(\mathbf{2 7 \% )}$ & $\mathbf{( 3 0 \% )}$ & $\mathbf{( 4 3 \% )}$ & $\mathbf{( 1 0 0 \% )}$ \\
\hline
\end{tabular}

Tabel 5 menunjukkan bahwa Ibu yang memiliki kadar lemak baik maka bayi memiliki penambahan berat badan bayi normal bahkan lebih. Dari 37 responden 19 responden memiliki kadar lemak baik, dari 19 responden yang memiliki kadar lemak baik 16 responden (84\%) mengalami kenaikan berat badan bayi lebih dan 3 responden (16\%) mengalami kenaikan berat badan normal

\section{Analisis Data}

Uji normalitas KolmogorovSmirnov menggunakan program SPSS dengan taraf kesalahan $\alpha=0,05$, maka diperoleh nilai signifikansi sebesar 0,558 untuk kadar lemak dan 0,271 untuk penambahan berat badan bayi. Hasil ini menunjukkan bahwa nilai signifikansi seiap variabel lebih besar dari 0,05 sehingga dapat disimpulkan bahwa data yang di uji berdistribusi normal.

Uji analisa Pearson Product Moment dengan taraf kesalahan $\alpha=0,05$ dan $\mathrm{dk}=\mathrm{n}-2=35$, maka diperoleh nilai $\mathrm{r}$ hitung $=0,706$ dan nilai $r_{\text {tabel }}=0,325$. Hasil ini menunjukkan bahwa nilai $r$ hitung $=$ $0,706>\mathrm{r}_{\text {tabel }}=0,325$ sehingga secara statistik dapat disimpulkan $\mathrm{H}_{\mathrm{o}}$ ditolak dan $\mathrm{H}_{1}$ diterima. Hasil ini menunjukkan adanya hubungan antara kadar lemak dalam ASI Matur dengan penambahan berat badan bayi. Hasil $r$ hitung bertanda positif menunjukkan bahwa arah korelasi positif atau berbanding lurus, artinya jika kadar lemak mengalami peningkatan maka berat badan bayi akan mengalami penambahan berat badan. Berpedoman pada tabel interpretasi tingkat hubungan menurut Sugiyono (2010), nilai $r$ hitung $=$ 0,706 termasuk dalam tingkat hubungan kuat. Selanjutnya, Pengujian signifikansi koefisien korelasi dilakukan dengan uji t hitung. Uji $t$ hitung berfungsi untuk memperkuat hasil arah uji $\mathrm{r}$ pada pearson product moment. Pada hasil uji $\mathrm{t}$ didapatkan nilai $\mathrm{t}_{\text {hitung }}=5,897>\quad \mathrm{t}_{\text {tabel }}$ $=2.021$ sehingga dapat disimpulkan Ho ditolak dan arah korelasi kedua variabel bernilai positif.

\section{PEMBAHASAN}

Hasil pengukuran kadar lemak pada 37 responden yang diteliti menunjukkan 19 responden (51 \%) memiliki kadar lemak baik. Kadar lemak bisa dipengaruhi oleh umur bayi. Umur bayi berkaitan dengan waktu di produksi ASI atau klasifikasi ASI. ASI matur diproduksi hari ke 10 sampai minggu ke 3 - 5 dan komposisinya relatif konstan (Marmi,2012). Kadar lemak ASI seharusnya semakain bertambah dengan mengikuti pertambahan kebutuhan bayi sesuai pertambahan usianya. Dalam penelitian ini jumlah bayi umur 1 bulan (23 responden) lebih banyak dari bayi usia 2 bulan (14 responden). Bayi umur 1 bulan sebanyak 12 responden (52\%) memiliki kadar lemak baik dan 11 responden (48\%) memiliki kadar lemak tidak baik. Demikian pula pada bayi umur 2 bulan, masing - masing 7 responden $(50 \%)$ memiliki kadar lemak baik dan tidak baik. Pertambahan kadar lemak ASI seharusnya mengikuti pertambahan kebutuhan bayi setiap bulan. Dalam penelitian ini masih 
belum dapat ditemukan perbedaan yang signifikan dikarenakan pengambilan sampel masih kurang seimbang antara bayi umur 1 bulan dengan umur 2 bulan.

Ada beberapa faktor yang dapat mempengaruhi kadar lemak dalam ASI, salah satunya adalah alat kontrasepsi yang digunakan oleh ibu. Alat kontrasepsi yang digunakan oleh ibu memiliki pengaruh terhadap komposisi dan volume ASI. Penggunaan kontrasepsi hormonal kombinasi estrogen dan progestin berkaitan dengan penurunan volume dan komposisi ASI (Koetsawang, 1987 dan Lonerdal, 1986 dalam ACC/SCN, 1991), sebaliknya bila alat kontrasepsi hanya mengandung progestin tidak ada dampak terhadap volume dan komposisi ASI (WHO Task Force on Oral Contraceptives, 1988 dalam ACC/SCN, 1991). Berdasarkan hal ini WHO merekomendasikan alat kontasepsi hormonal yang hanya mengandung progestin untuk ibu menyusui (Nugroho,2011). Dalam penelitian ini 18 responden ibu tidak menggunakan alat kontrasepsi, 11 responden $(61 \%)$ diantaranya memiliki kadar lemak baik. Pemakaian kontrasepsi hormonal dapat mempengaruhi volume dan kandungan ASI (Nugroho,2011) sehingga SDKI 2007, merekomendasikan metode kontrasepsi nonhormonal untuk ibu menyusui karena tidak memiliki pengaruh yang sigifikan pada volume dan kangdungan ASI.

Hasil pengukuran penambahan berat badan bayi menunjukkan bahwa 16 responden (43\%) termasuk dalam kategori penambahan berat badan lebih, 12 responden umur 1 bulan dan dan 4 responden umur 2 bulan; 11 responden (30 \%) termasuk dalam kategori penambahan berat badan normal, 7 responden umur 1 bulan dan 4 responden umur 2 bulan; serta 10 responden $(27 \%)$ termasuk dalam kategori penambahan berat badan kurang, 4 responden umur 1 bulan dan 6 responden umur 2 bulan. Menurut Sumitro (1986) dalam Maryunani (2010) berpendapat bahwa penambahan badan badan bayi pascanatal (29 hari/1 bulan -1 tahun) terjadi sangat signifikan. Penambahan berat badan bayi biasanya pada tiga bulan pertama $700-1.000$ gram/bulan, berat badan menjadi 2 kali berat badan waktu lahir pada saat bayi umur 5 bulan, menjadi 3 kali berat badan lahir pada umur 1 tahun, dan menjadi 4 kali berat badan lahir pada umur 2 tahun. Penambahan berat badan bayi pada triwulan pertama terjadi secara signifikan hal ini dipengaruhi oleh beberapa faktor salah satunya adalah asupan bayi yaitu pemberian ASI. Pemberian ASI yang baik dapat memenuhi $50 \%$ kebutuhan energi yang dibutuhkan oleh tubuh bayi sehingga pertumbuhan dan perkembangannya dapat berjalan sesuai dengan tahapan usianya.

Hasil pengukuran pada penelitian ini menunjukkan dari 37 responden didapatkan 19 responden $(51 \%)$ memiliki kadar lemak baik dan seluruhnya mengalami kenaikan berat badan yaitu 3 responden (16\%) mengalami kenaikan berat badan normal dan 16 responden (84 \%) mengalami kenaikan berat badan lebih. Penelitian ini juga menunjukkan bahwa 18 responden memiliki kadar lemak tidak baik, 8 reponden (44\%) mengalami kenaikan berat badan normal dan 10 responden $(56 \%)$ mengalami kenaikan berat badan kurang.

Menurut Monika (2015), Lemak banyak terdapat pada ASI matur yaitu pada fase hindmilk, ASI pada fase hindmilk cenderung lebih kental dan kaya lemak yang sangat berperan dalam pertambahan berat badan bayi serta memenuhi 50\% kebutuhan energi bayi. Selain jumlahnya yang mencukupi, jenis lemak yang ada dalam ASI mengandung lemak rantai panjang yang merupakan lemak kebutuhan sel jaringan otak dan memiliki asam linoleat yang cukup tinggi. Lemak ASI mudah dicerna dan diserap oleh bayi karena ASI juga mengandung enzim lipase yang mencerna lemak trigliserida menjadi digliserida, sehingga sedikit lemak yang tidak diserap oleh sistem pencernaan bayi. Hasil pengukuran 
pada penelitian ini menunjukkan responden dengan kadar lemak ASI baik memiliki penambahan berat badan normal bahkan lebih., sedangkan responden yang memiliki kadar lemak tidak baik juga memiliki penambahan berat badan, baik penambahan berat badan yang normal maupun kurang. Hal tersebut dikarenakan terdapat faktor lain yang dapat mempengaruhi berat badan bayi seperti kandungan makronutrien lain dalam ASI, keturunan serta usia kehamilan saat melahirkan. Penelitian sebelumnya yang dilakukan oleh Rogawski (2005) yang meneliti tentang pemberian lemak pada bayi yang lahir prematur melalui pemberian asupan lemak parenteral melalui infus menunjukkan hasil bahwa dapat mengurangi resiko terjadinya kekurangan asam lemak bebas (Free Fat Acids/FFA) dan mencegah kekurangan asam lemak essesnsial (Essential Fatty Acids/EFA). Lemak yang terdapat dalam ASI adalah lemak rantai panjang dan terkonsentrasi baik dalam tubuh bayi, dengan bantuan enzim lipase yang mencerna lemak trigliserida menjadi digliserida membuat sedikit lemak yang tidak diserap oleh sistem pencernaan bayi sehingga mampu membantu pertumbuhan berat badan bayi karena lemak dalam ASI dapat memenuhi 50\% kebutuhan energi yang dibutuhkan oleh bayi sesuai dengan tahapan usianya.

\section{KESIMPULAN}

Berdasarkan hasil penelitian dapat disimpulkan bahwa :

a. 18 responden (49\%) memiliki kadar lemak tidak baik dan 19 responden ( $51 \%$ ) memiliki kadar lemak baik.

b. 16 responden $(43 \%)$ mengalami kenaikan berat badan lebih; 11 responden $(30 \%)$ mengalami kenaikan berat badan normal; serta 10 responden (27 \%) mengalami kenaikan berat badan lebih

c. Ada hubungan yang signifikan antara kadar lemak dalam ASI Matur dengan penambahan berat badan bayi umur 1 -
2 bulan dan termasuk dalam tingkat hubungan kuat. Semakin tinggi kadar lemak dalam ASI Matur maka penambahan berat badan bayi akan semakin meningkat.

\section{DAFTAR PUSTAKA}

Ambarwati, E.Retna, Wulandari D. 2009. Asuhan kebidanan nifas. Jogjakarta: Mitra Cendikia Press.

Andriani, Merryana. 2012. Peranan gizi dalam siklus kehidupan. Jakarta: Kencana

Arifin, Siregar. 2006. Pemberian ASI eksklusif dan faktor-faktor yang mempengaruhinya. Sumatra Utara: Universitas Sumatra Utara.

Badriul, Hegar. 2008. Bedah ASI. Jakarta: Balai Pustaka FKUI.

Departemen Kesehatan RI. 2009. Petunjuk pelaksanaa peningkatan ASI. Jakarta: Depkes RI

Hidayat A A A. 2008. Pengantar Kesehatan Anak untuk Pendidikan Kebidanan. Jakarta: Salemba Medika

Hubertin, SP. 2003. Konsep penerapan ASI eksklusif: Buku Saku Untuk Bidan. Jakarta: EGC

Hubertin, SP. 2004. Konsep penerapan ASI eksklusif, Jakarta : EGC.

Jennifer.1986. ASI dan Pertumbuhan Emas Bayi. Jakarta : Salemba Medika

Marmi. 2012. Asi saja mama, berilah aku asi karena aku bukan anak sapi (Panduan lengkap manajemen laktasi). Yogyakarta: Pustaka Pelajar

Maryunani, Anik. 2009. Asuhan pada ibu dalam masa nifas (Postpartum). Jakarta: TIM

Monika. 2015. Buku Pintar ASI dan Menyusui. Jakarta: Noura Books

Nisman W A, Mera M E, Sandi A, Lesmana S. 2011. Panduan Pintar Ibu menyusui. Yogyakarta : Andi Offset

Notoadmodjo, S. 2007. Promosi kesehatan dan ilmu perilaku kesehatan. Jakarta: Rineka Cipta. 
Notoatmodjo, S. 2012. Metodologi penelitian kesehatan. Jakarta: Rineka Cipta

Nugroho, T. 2011. ASI dan Tumor Payudara. Bantul : Nada Medika

Nursalam; Rekawati, Susilaningrum, Sri U. 2008. Asuhan Keperawatan Bayi dan Anak . Jakarta : Salemba Medika

Potter, Perry. 2005, Fundamental Keperawatan, Volume 1, edisi, EGC

Prasetyo. 2008. Buku pintar ASI eksklusif. Jakarta : EGC

Purbantini. 2010. ASI Eksklusif bagi Bayi. Jakarta : Salemba Medika

Rogawski \& Elizabeth T. 2005. Journal of Pediatric Gastroenterology \& Nutrtition Vol. 41, Suppl. 2

Ruliana, Suradi. 2004. Manajemen laktasi. Menuju persalinan aman dan bayi lahir sehat, 2nd ed. Jakarta: Perinasia

Sinsin, Iis. 2008. Seri kesehatan ibu dan anak masa kehamilan dan persalinan. Jakarta: Alex Media.

Soetjiningsih, 1995. Tumbuh Kembang Anak. EGC. Penerbit Buku Kedokteran. Jakarta.

Soetjiningsih. 1999. ASI petunjuk untuk tenaga kesehatan. Jakarta: EGC

Sugiyono. 2015. Statistik untuk Penelitian. Bandung: Alfabeta

Supariasa. 2012. Penilaian status gizi edisi revisi. Jakarta: EGC

Wong, Whaley's. 2001. Psikologi Perkembangan Anak Dan Remaja, Remaja Rosda Karya, Bandung Edisi 1. Jakarta: Salemba Medika 